\title{
Currarino syndrome
}

\author{
Ramesh S. Iyer • Paritosh C. Khanna
}

Received: 17 June 2010 /Revised: 29 June 2010 /Accepted: 8 July 2010/Published online: 10 August 2010

(C) Springer-Verlag 2010

A 58-week-old girl presented with chronic constipation. MRI demonstrated sacral dysgenesis, a low-lying conus and a small syrinx (Figs. 1 and 2). Protruding through a ventral sacral defect was a heterogenous fatty mass with intralesional nodules (Fig. 1). Interval nodular enlargement and elevated alpha-fetoprotein (AFP) led to resection of the mass, due to concern for a malignant teratoma. The lesion was proved to be pathologically benign dermoid. The patient had pelvic floor abnormalities and an HLXB9 gene deletion on the $7 \mathrm{q} 36$ locus, consistent with Currarino syndrome.

The Currarino triad, as first described in 1981, consists of 1) an anorectal malformation, 2) an anterior sacral defect and 3) a presacral mass, which may be a teratoma, meningocele, neurenteric cyst or combined lesion [1]. Currarino syndrome includes clinical findings such as a bowel obstruction, along with gynecological and renal malformations. Mass resection is advised due to organ compression and the risk of malignant degeneration [2].

\section{References}

1. Currarino G, Coln D, Votteler T (1981) Triad of anorectal, sacral, and presacral anomalies. AJR 137:395-398

2. Lynch SA, Wang Y, Strachan T et al (2000) Autosomal dominant sacral agenesis: Currarino syndrome. J Med Genet 37:561-566

R. S. Iyer $(\bowtie)$

Pediatrics Division, Department of Radiology R-5438,

Seattle Children's Hospital,

4800 Sand Point Way NE,

Seattle, WA 98105-3901, USA

e-mail: rameshsiyer@gmail.com

\section{P. C. Khanna}

Pediatrics Division, Department of Radiology,

University of Washington, Seattle Children's Hospital,

R-5417 Radiology, 4800 Sand Point Way NE,

Seattle, WA, USA

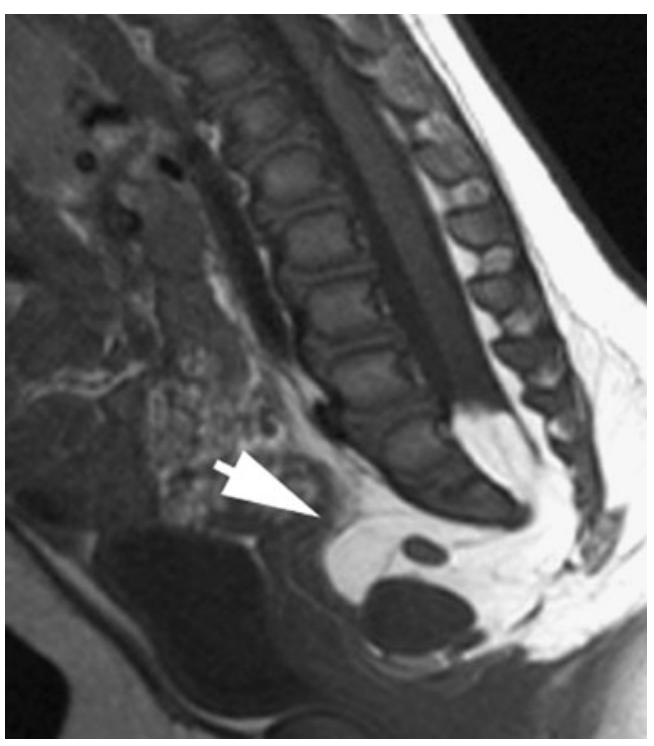

Fig. 1 Sagittal T1-W lumbar spine

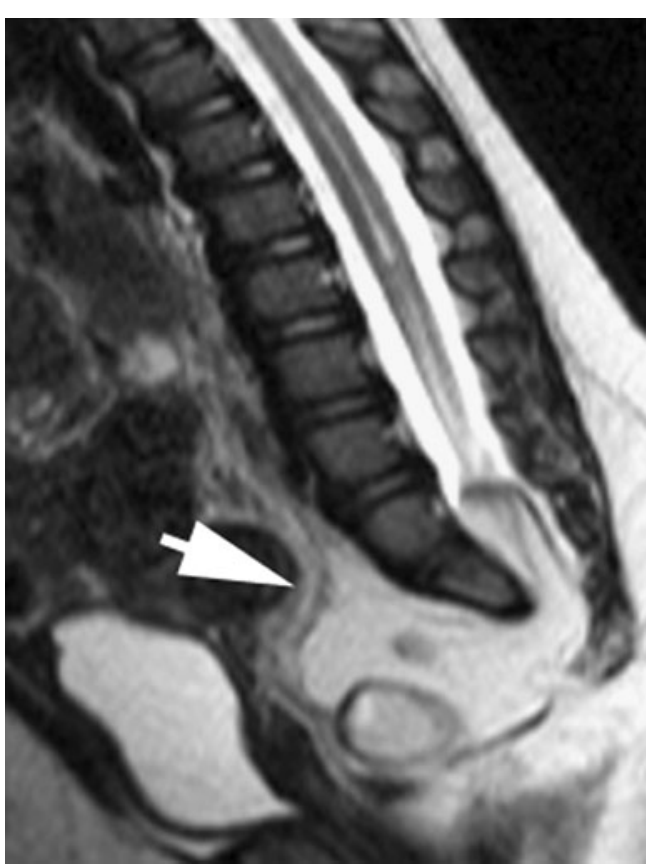

Fig. 2 Sagittal T2-W lumbar spine 